The Making of the Twentieth Century Available in Papermacs

\section{Christopher Thorne}

The Approach of War 1938-1939

'A brilliant narrative summary of the main political memoirs and collections of diplomatic documents ... A masterpiece of condensation, brilliantly but unobtrusively annotated, and an excellent introduction into the bargain' - D. C. Watt, Spectator

\section{David Rees}

The Age of Containment:

The Cold War 1945-1965

'I think it is an excellent piece of work... Rees has managed to treat a very difficult subject dispassionately and objectively and above all has packed into a very small space an extraordinary amount of very useful information' - Leonard Schapiro

\section{Anthony Harrison}

The Framework of Economic Activity: The International Economy and the Rise of the State

'A comprehensive and interesting review of the whole process of the rise of economic planning and the expansion of the public sector' - Times Literary

Supplement
A. J. Nicholls Weimar and the Rise of Hitler An introduction to the political history of the Weimar Republic and the crucial failure of Germi democracy in the years after th First World War that led to the rise of Adolf Hitler 


\section{The Making of the Twentieth Century}

This new series of specially commissioned titles focuses attention on significant and often controversial events and themes of world history this century. The authors, many of them already outstanding in their field, have tried to close the gap between the intelligent layman, whose interest is aroused by recent history, and the specialist student at university. Each book will therefore provide sufficient narrative and explanation for the newcomer while offering the specialist student detailed source-references and bibliographies, together with interpretation and reassessment in the light of recent scholarship.

In the choice of subjects there will be a balance between breadth in some spheres and detail in others; between the essentially political and matters scientific, economic or social. The series cannot be a comprehensive account of everything that has happened in the twentieth century, but it will provide a guide to recent research and explain something of the times of extraordinary change and complexity in which we live. 
The Making of the Twentieth Century

Series Editor: GHRISTOPHER THORNE

Other titles in the Series include

\begin{abstract}
Already published
Anthony Harrison, The Framework of Economic Activity:

The International Economy and the Rise of the State

A. J. Nicholls, Weimar and the Rise of Hitler

David Rees, The Age of Containment: The Cold War

Christopher Thorne, The Approach of War, 1938-1939
\end{abstract}

In preparation

Mark Abrams, The Rise of Public Opinion Dennis Austin, Africa: The Transfer of Power

Peter Calvert, Latin America : Internal Conflict and International Peace

John Erickson, The Revolution in Power: Strategy and Politics 1931-1947

M. W. Flinn, The Development of the Welfare State in Europe George Grün, The Illusion of Peace: International Relations 19I8-1933

Anthony Hartley, Germany: East/West

C. P. Hill, Government, Business and People: The U.S.A. in the

Twentieth Century

C. P. Hill, Isolation and Involvement: The United States and the World in the Twentieth Century

Alex Keller, Science and Social Change

Desmond King-Hele, The End of the Twentieth Century?

Hans Kohn The Racial Problem in the Twentieth Century

Diana Lary, Regionalism and Nationalism in Republican China John Madge, The Human Consequences of Urbanisation Peter Mansfield, The Ottoman Empire and its Successors J. Miller, The Impact and Development of Marxism in the Twentieth Century

J. Miller, Igr 7 in Russian and World History

Roger Morgan, Sovereignty, Nationalism and Supranationalism

B. N. Pandey, The Break-up of British India

B. N. Pandey, Problems of Independence in South and South-East Asia

P. B. Reddaway, Literature and Politics in the Soviet Union

E. M. Robertson, Mussolini, Abyssinia and the League

E. M. Robertson, The European Powers and the Spanish Civil War

Richard Storry, Japan and the Decline of the West in Asia

Elizabeth Wiskemann, Italian Fascism: Its Development and Influence

R. G. Wofinden and A. W. Macara, Population, Resources and

Public Health

John Wren-Lewis, Doubt and Belief in the Twentieth Century 


\section{Britain and France in the Middle East and North Africa, 1914-1967}

Ann Williams

Macmillan Education

I 968 
ISBN 978-0-333-05376-8 ISBN 978-1-349-15279-7 (eBook)

DOI 10.1007/978-1-349-15279-7

(C) Ann Williams I968

Published by

MAGMILLAN AND GO LTD

Little Essex Street London wc2

and also at Bombay Calcutta and Madras

Macmillan South Africa (Publishers) Pty Ltd Johannesburg

The Macmillan Company of Australia Pty Ltd Melbourne

The Macmillan Company of Canada Ltd Toronto

St Martin's Press Inc New York

Library of Congress catalog card no. 68-2656I 
FOR

Elizabeth Monroe; West Hendred and Oxford 


\section{Contents}

List of Plates and Maps ix

Preface $\quad$ xi

List of Abbreviations xiii

introduction: The Middle East, the Maghrib and the West

I Problems in War and Peace 9

2 International Trusteeship in the Levant 23

3 British Interests in the Middle East $\quad 3^{8}$

4 The French in North Africa 57

5 Resistance Movements and Old Policies 75

6 North Africa en marche $\quad 93$

7 The Way to Suez III

8 The Years after Suez I3

Postscript: Britain and France in the Middle East and North Africa $\quad 150$ 
viii GONTENTS

APPENDIX

Note on the historiography of Suez and the issue of collusion

I 55

Chronological Table

I 59

Bibliography

I65

Index

185 


\title{
Plates and Maps
}

\author{
PLATES \\ between pages 146 and 147 \\ Ia The Cairo Conference of 1921 \\ $b$ The Balfour Declaration \\ $2 a$ The Mosul Commission, 1925 \\ b Amir Abdullah of Transjordan \\ c General Lyautey \\ 3 Lord Plumer \\ 4a General Gouraud \\ $b$ The pipeline from Kirkuk to Banias under con- \\ struction in 1952 \\ 5 Blowing up of the King David Hotel, July 1946 \\ Plastic bomb explosion in Paris, January 1962 \\ 6 and 7 Characters in Suez drama \\ M. Pineau and Sir Anthony Eden, Mr John Foster \\ Dulles, M. Mollet, Mr David Ben Gurion, Presi- \\ dent Nasser \\ 8 M. Habib Bourguiba \\ President de Gaulle
}

The author and publishers wish to thank the following for permission to reproduce the plates: 5 (lower), Associated Press; 16 , British Museum; 8 (lower), André Debatty from Le I3 Mai et la Presse (published by Armand Colin); $2 a$, Mr C. J. Edmonds; (upper), Imperial War Museum; $4 b$, Iraq Petroleum Company; 6 (lower), 7 (top left), Keystone; $1 a, 2 b$ and $c, 3,4 a$, 6(upper), 7 (top and bottom right), The Radio Times Hulton Picture Library; 8 (upper), Tunisian Embassy.

The cartoon on page 108 is by Pol Ferjac and originally appeared in Le Canard Enchaîné. 


\section{MAPS}

I The Middle East in 1926 xiv

2 The Sykes-Picot Agreement of I9I6 I2

3 The Middle East in $1956 \quad 132$

\section{ACKNOWLEDGEMENTS}

The author and publishers wish to thank the following for permission to reproduce the maps:

Maps 1 and 3: Messrs Chatto \& Windus, based on a map in E. Monroe, Britain's Moment in the Middle East.

Map 2: Khayat's, Beirut, based on a map in Zeine $\mathbf{N}$. Zeine, The Struggle for Arab Independence. 


\section{Preface}

THE scope of this book is indicated by its title, but even within these limits it is necessarily selective in its material. It is hoped that the Bibliography will enable those interested to follow up the political history of individual countries, and also social and economic changes in the Middle East and North Africa in the present century.

The transliteration of Arabic, Turkish and Persian personal names and place-names has, as always, given rise to many problems. As many of the people mentioned are familiar to newspaper readers in certain guises, for example, Nasser and Bourguiba, I have thought it best to leave them like this, but have in the process produced an untidy mixture of French and English transliteration.

I thank my mother for typing the manuscript. I should also like to thank the Librarian, and Miss Myrtle Matthews and the counter staff of King's College Library, Aberdeen; the Librarian of St Antony's Middle East Centre; the Librarian and staff of the School of Oriental and African Studies; the Librarian and staff of Chatham House Library; and also the Librarian and staff of the London Library for their kindness in providing books. The dedication of the book is an inadequate return for the help and friendship of Elizabeth Monroe. 


\section{Abbreviations}

D.B.F.P. i Documents on British Foreign Policy, series i

D.I.A. 1956 R.I.I.A., Documents on International Affairs 1956, ed. Noble Frankland (London, 1959)

Hurewitz, ii J. G. Hurewitz, Diplomacy in the Near and Middle East, vol. ii, 1914-1956 (Princeton, 1956)

Julien Ch.-A. Julien, L'Afrique du Nord en marche, 2nd ed. (Paris, r953)

Le Tourneau Roger Le Tourneau, L'Evolution politique de L'Afrique du Nord Musulmane (Paris, 1962)

Monroe Elizabeth Monroe, Britain's Moment in the Middle East (London, 1963) 


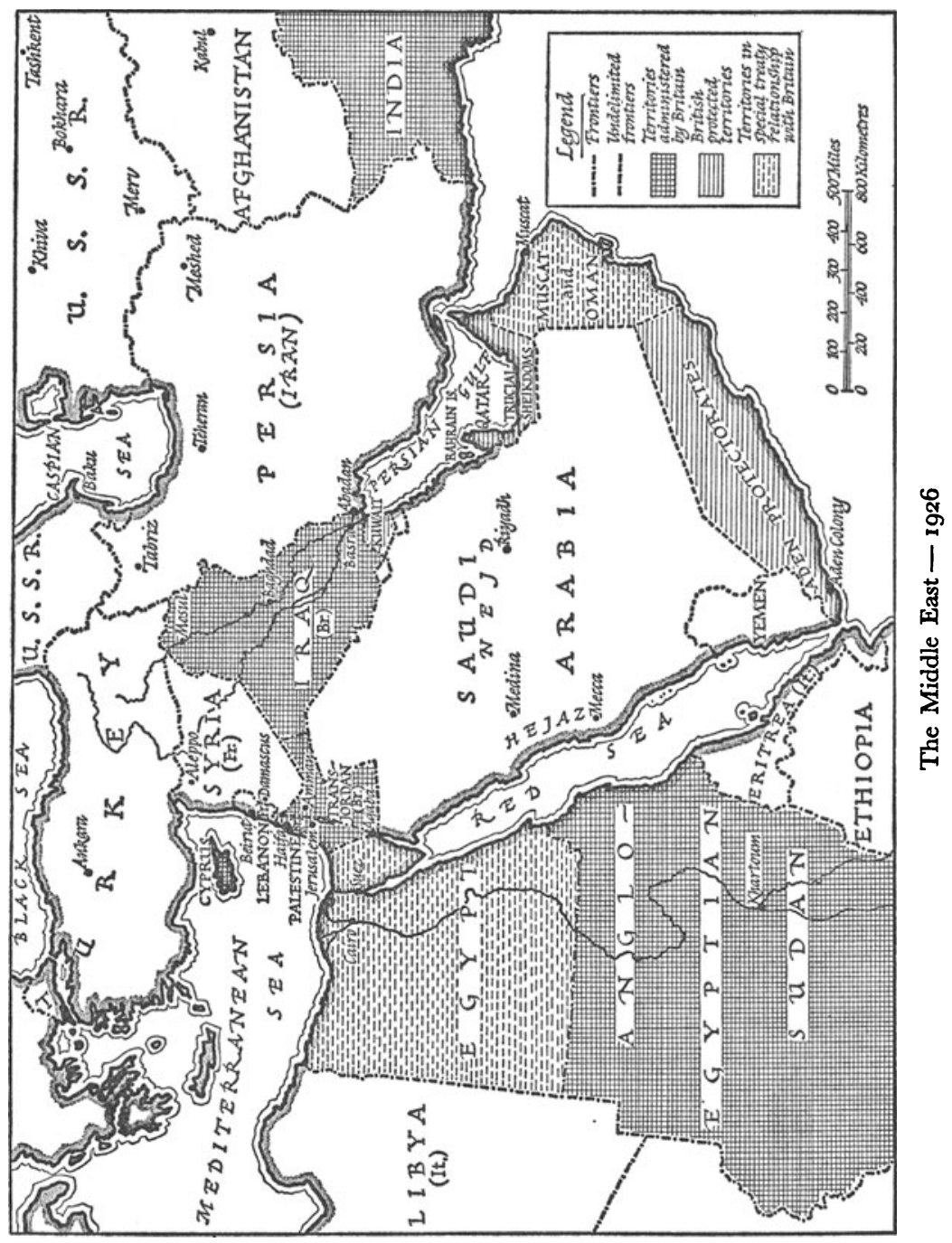

